\title{
Bacaba powder produced in spouted bed: an alternative source of bioactive compounds and energy food product
}

\author{
Bacaba em pó produzido em leito de jorro: uma fonte \\ alternativa de compostos bioativos e um produto alimentar \\ energético
}

\section{Rafael Alves do Nascimento1* (D), Elisângela Lima Andrade1, Elza Brandão Santana ${ }^{1}$ Nielson Fernando da Paixão Ribeiro ${ }^{1}$, Cristiane Maria Leal Costa ${ }^{1}$, Lênio José Guerreiro de Faria ${ }^{1}$}

${ }^{1}$ Universidade Federal do Pará (UFPA), Programa de Pós-graduação em Engenharia Química (PPGEQ), Belém/PA - Brasil

*Corresponding Author: Rafael Alves do Nascimento, Universidade Federal do Pará (UFPA), Programa de Pós-graduação em Engenharia Química (PPGEQ), Rua Augusto Corrêa, 1, CEP: 66075-110, Belém/PA -

Brasil, e-mail: rafaelnascimentoa@gmail.com

Cite as: Nascimento, R. A., Andrade, E. L., Santana, E. B., Ribeiro, N. F. P., Costa, C. M. L., \& Faria, L. J. G. (2019). Bacaba powder produced in spouted bed: an alternative source of bioactive compounds and energy food product. Brazilian Journal of Food Technology, 22, e2018229. https://doi.org/10.1590/1981-6723.22918

\begin{abstract}
This study evaluated Bacaba powder produced in a spouted bed as a source of bioactive compounds and high energy value. The conditions influencing the drying process parameters (yield, moisture level, phenolic and anthocyanin retention) as well as simultaneous optimization (optimal conditions) of production were also considered. Drying was most efficient at $75{ }^{\circ} \mathrm{C}$ using maltodextrin concentrations above $20.0 \%(\mathrm{w} / \mathrm{w})$. Higher anthocyanin retention $(92.52 \%)$ at $65^{\circ} \mathrm{C}(p=0.0003)$, and a maltodextrin concentration of $20.0 \%(\mathrm{w} / \mathrm{w})$ resulted in high retention of phenolics $(95.38 \%)$. Accordingly, the operations tested under the desirability function $\left(68{ }^{\circ} \mathrm{C}\right.$, maltodextrin concentration of $21.7 \% \mathrm{w} / \mathrm{w}$, and air velocity of $1.3 \times$ minimum spouting velocity $\left.\left(V_{j m}\right) \mathrm{m} \mathrm{s}^{-1}\right)$ resulted in a process yield of $55.04 \%$ and the dry basis (d.b.) composition results were: total phenolics (376.43 mg GAE $\left.100 \mathrm{~g}^{-1}\right)$, energetic value (612.64 kcal $\left.100 \mathrm{~g} \mathrm{~g}^{-1}\right)$, lipids

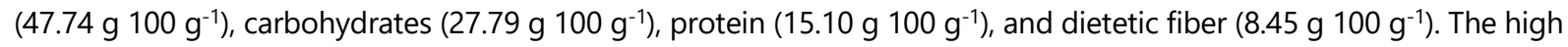
solubility (92\%), flowability (14\%), energy, and bioactive characteristics of Bacaba powder suggest the potential for many applications, such as development of dietary supplements, high-energy drinks, milk-based and instant products, and bakery products.
\end{abstract}

Keywords: Energy value; Phenolic compound; Oenocarpus bacaba; Spouted bed drying.

\section{Resumo}

Este estudo avaliou o pó de bacaba produzido em leito de jorro como fonte de compostos bioativos e de alto valor energético. As condições que influenciaram os parâmetros do processo de secagem (desempenho, teor de umidade, retenção fenólica e de antocianina), bem como a otimização simultânea (condições ótimas) de produção foram consideradas. A secagem foi mais eficiente a $75{ }^{\circ} \mathrm{C}$ usando maltodextrina em concentrações acima de $20 \%(p / p)$. A 
retenção de antocianinas foi alta $(92,52 \%)$ a $65^{\circ} \mathrm{C}(p=0,0003)$, e uma concentração de maltodextrina de $20 \%(p / p)$ resultou em alta retenção de fenólicos $(95,38 \%)$. Assim, nas operações testadas sob a função desejabilidade $\left(68^{\circ} \mathrm{C}\right.$, concentração de maltodextrina de 21,7\% p/p e velocidade do ar de 1,3 $\times$ velocidade de jorro mínimo $\left.\left(V_{j m}\right) \mathrm{m} \mathrm{s}^{-1}\right), 0$ rendimento do processo foi de 55,04\%, e os resultados de composição em base seca (b.s.) foram: fenólicos totais, $376,43 \mathrm{mg} \mathrm{GAE} 100 \mathrm{~g}^{-1}$; valor energético, 612,64 kcal $100 \mathrm{~g}^{-1}$; lipídios, 47,74 g $100 \mathrm{~g}^{-1}$; carboidratos, 27,79 g $100 \mathrm{~g}^{-1}$;

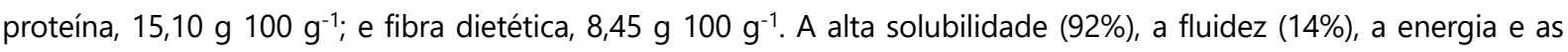
características bioativas do pó de bacaba sugerem seu potencial uso em muitas aplicações, como no desenvolvimento de suplementos dietéticos, bebidas de alta energia, produtos à base de leite, instantâneos e de confeitaria.

Palavras-chave: Valor energético; Compostos fenólicos; Oenocarpus bacaba; Secagem em leito de jorro.

\section{Introduction}

Phenolic compounds are the most active and prevalent antioxidants in vegetables, fruits, and processed foods. Due to several structural combinations, these phytochemicals are divided in different classes based on the main sources of phenolic antioxidants: flavonoids, phenolic acids, tannins, and tocopherols (Shahidi \& Ambigaipalan, 2015). Anthocyanins are phenolic compounds of the flavonoid class, found particularly in dark-colored and red fruits. They are soluble in water and used in preparing industrial colors, astringents, and scents, and for promoting oxidative stability of food (Castañeda-Ovando et al., 2009).

The antioxidant properties of phenolic compounds are essential, and they extend the shelf life of food products without adverse effects on nutritional and sensory qualities. Moreover, chemically and biologically interesting properties have been observed, as the protective effects of these compounds on human health, particularly in preventing oxidation, cardiovascular disease, cancer, diabetes, and obesity (Dias et al., 2017).

In this context, the search for sources of natural antioxidants that not only act as substitutes for synthetic antioxidants and as stabilizers of lipid oxidation, but also can add nutritional value and provide bioactive compounds by incorporation into food matrices, is crucial (Shahidi \& Ambigaipalan, 2015).

The Amazonian region has several varieties of fruits that were unknown until recently and that are receiving relevance owing to their excellent flavor, nutritional characteristics, and potential antioxidant activity (Neri-Numa et al., 2018). One such is the palm Bacaba, Oenocarpus bacaba Mart., whose fruit pulp is normally consumed, presenting a pleasant taste and a milky-cream color. This fruit (harvested from January to July) has high exploratory value for agro-industrial purposes, and it is a potential source of natural antioxidants and energy food (Abadio Finco et al., 2012).

Although the use in folk medicine predicts the functional properties of Bacaba fruits, their nutritional and bioactive potential has not yet been sufficiently studied (Abadio Finco et al., 2016). Several benefits associated with their consumption are reported, such as antioxidant (Leba et al., 2016) and antiproliferative activity (Abadio Finco et al., 2013), and potential chemopreventive activity against carcinogenesis (Abadio Finco et al., 2016).

Angelo \& Jorge (2007) confirmed that phenolic compounds mainly occur in citrus and tropical fruits, and that they are found in greater quantities in pulp than in fruit juice. However, the high degree of perishability and oxidation of pulps motivates research on processing methods that reduce the degradation of these compounds. The viable solution, described in specialized literature, is the use of spouted beds for drying of products.

Drying of fruit pulps in spouted bed is recommended with the addition of carrier agents; however, when unused, they can generate agglomerated products on the dryer wall instead of a dry powder. In this context, maltodextrin is the most used coadjuvant in function of high solubility in cold water, low hygroscopicity and lower cost. In addition, due to the high molecular weight, the addition of maltodextrin increases the glass 
transition temperature of the suspension, impacting on higher yields and facilitating subsequent transport and storage operations (Bhandari et al., 1997).

The products in powder form thus obtained retain the content of bioactive compounds and maintain excellent quality (Wachiraphansakul \& Devahastin, 2007). Therefore, spouted bed technology is usually recommended for thermosensitive materials as it operates at lower temperatures than other dryers such as spray dryers (Fujita et al., 2013).

The present study evaluates Bacaba powder, produced by drying the fruit pulp on a spouted bed, as a novel source of phenolics and anthocyanins. With the intention of promoting the use of the product in industry, the study describes the optimization of the production process as well as the bioactive, energetic, and physical characteristics of Bacaba powder.

\section{Material and methods}

\subsection{Materials}

Bacaba pulp was obtained from a commercial establishment in Belém (State of Pará, Brazil), transported in hermetically sealed boxes and stored at $-18{ }^{\circ} \mathrm{C}$, being thawed as per the requirements of each experiment. MOR-REX® 1910 maltodextrin (Ingredion Brasil Ingredientes Industriais Ltda., Sao Paulo, Brazil) with dextrose equivalent 10 was used as a coadjuvant in the drying process. Thawed Bacaba pulp was diluted in distilled water $(3: 1, \mathrm{w} / \mathrm{w})$ to avoid clogging the atomizer nozzle. Maltodextrin was added to the diluted Bacaba pulp according to the amount required for each assay and was stirred magnetically until complete dissolution.

\subsection{Spouted bed}

The drying process of Bacaba-maltodextrin pastes was carried out in a conventional spouted bed with cone-cylindrical geometry. The spouted bed was composed of an acrylic cylinder with an inner diameter of $0.16 \mathrm{~m}$, and $0.8 \mathrm{~m}$ high. The cone part is $0.15 \mathrm{~m}$ high and has an air inlet with a diameter of $0.0254 \mathrm{~m}$ at an angle of $60^{\circ}$. The experimental scheme is shown in Figure 1. The atomization pressure used in the drying experiments was approximately $68.95 \mathrm{kPa}$, with an average flow rate of $5.5 \mathrm{~mL} \mathrm{~min}{ }^{-1}$. The pastes were magnetically stirred five times under an intermittent regime (10-minute intervals) during the process. The amount of paste used in each experiment was approximately $0.30 \mathrm{~kg}$. The high-density polyethylene (HDPE) particles used in the drying experiments had an average diameter of $3.17 \pm 0.23 \mathrm{~mm}$ and a real specific mass of $970 \pm 0.06 \mathrm{~kg} \mathrm{~m}^{-3}$, characterizing it as a type D powder according to the classification of Geldart (1973). For each experimental trial, $1.0 \mathrm{~kg}$ of HDPE was used, corresponding to a fixed bed height of $0.12 \mathrm{~m}$. Fluid dynamics tests were performed on the inert material to obtain the minimum velocity necessary for spout regime outflow $\left(\mathrm{V}_{\mathrm{jm}}\right)$. The film covering the HDPE particles is dried by the convective hot air stream and by the contact with the inert particles heated by thermal conduction. Throughout drying, the film becomes brittle and, due to the inter-particle and particle-wall collisions, it fractures and is released in the air stream. The powder produced is collected by a Lapple cyclone constructed in $5 \mathrm{~mm}$ thick acrylic resin. 


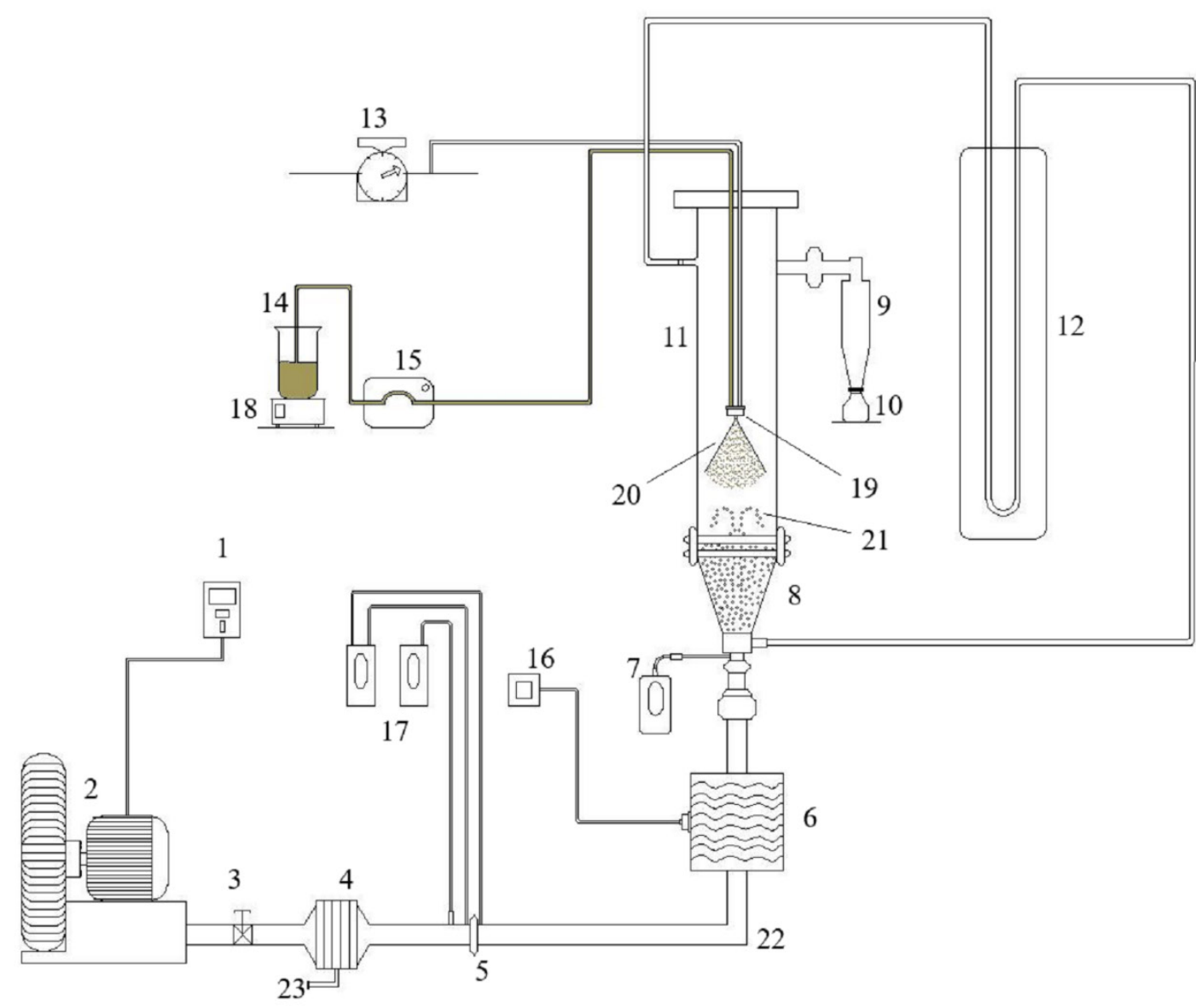

Figure 1. Experimental scheme. (1) Rotation/Frequency inverter; (2) Centrifugal blower; (3) Control valve; (4) Cooler; (5) Orifice plate; (6) Electrical heater; (7) Digital thermometer; (8) Conical bed base; (9) Cyclone;

(10) Powder collector; (11) Cylindrical column; (12) U-tube differential manometer; (13) Compressed air line;

(14) Paste; (15) Peristaltic pump; (16) PID controller of temperature; (17) Digital manometer; (18) Magnetic stirrer; (19) Spray nozzle; (20) Sprayed paste; (21) HDPE particles; (22) Galvanized steel pipe; (23) Water.

\subsection{Characterization of pastes and powder}

The Bacaba-maltodextrin pastes were characterized in terms of solid concentration (gravimetric method in an oven set to $105^{\circ} \mathrm{C}$ ), density (liquid pycnometry), contact angle (goniometer, ChemInstruments, Tantec Contact Angle Meter, model CAM-PLUS, OH, USA), and anthocyanin and total phenolic compound concentrations. The Bacaba powders obtained in the 15 experimental drying assays were analyzed for total phenolic and anthocyanin retention, moisture content, and yield. Under the optimum drying condition, the total phenolic compound and anthocyanin concentration, energy value, physical and chemical composition, moisture content, morphology, flowability, and solubility were determined.

\subsubsection{Total phenolic compound concentration}

The extract used for testing anthocyanins and phenolic compounds was prepared according to the method of Borges et al. (2016) using water as extractor solution. The total phenolic compound content was determined by UV-Vis spectrophotometry at a wavelength of $760 \mathrm{~nm}$, according to Georgé et al. (2005). An analytical curve was constructed using the gallic acid standard curve to quantify the total phenolic compound content. Results were expressed as gallic acid equivalent milligrams (mg GAE $100 \mathrm{~g}^{-1}$ ). 


\subsubsection{Total anthocyanin concentration}

Total anthocyanin content was determined according to the differential $\mathrm{pH}$ method, as described by Giusti \& Wrolstad (2001), using $0.025 \mathrm{M}$ potassium chloride (pH 1.0) and $0.4 \mathrm{M}$ sodium acetate (pH 4.5) buffer solutions. The absorbance values were measured on an Ultraviolet-Visible (UV-Vis) UV-1800 spectrophotometer (Shimadzu, Kyoto, Japan) at wavelengths of 510 and $710 \mathrm{~nm}$, and the concentration of anthocyanin was calculated according to Equation 1.

$$
C_{a}=\left[\left(A_{510}-A_{710}\right)_{p H 1.0}-\left(A_{510}-A_{710}\right)_{p H 4.5}\right] \times \frac{M W \times D F \times 1000}{\varepsilon \times l}
$$

where, $C_{a}$ is the anthocyanin concentration $\left(\mathrm{mg} \mathrm{L}^{-1}\right), A_{510}$ and $A_{710}$ correspond to the absorbance values of the samples read at 510 and $710 \mathrm{~nm}$, respectively, $M W$ is the molecular weight of cyanidin-3-glucoside (449.2 $\left.\mathrm{g} \mathrm{mol}^{-1}\right), D F$ the dilution factor, $\varepsilon$ the molar extinction coefficient of cyanidin-3-glucoside $\left(26,900 \mathrm{~L} \mathrm{~mol}^{-1} \mathrm{~cm}^{-1}\right)$, and $l$ the pathway length $(\mathrm{cm})$. Anthocyanin and phenolic retentions were calculated based on the difference between the concentrations of the bioactive compounds analyzed before and after the drying process on a dry basis.

\subsubsection{Physical and chemical composition and energy content}

Moisture (method 925.09 AOAC) lipid (method 31.4.02 AOAC), crude protein (Nx6.25) (method 920.87 AOAC), ash (method 923.03 AOAC), and total dietary fiber (method 985.29 AOAC) content were measured in both the Bacaba pulp and powder according to Association of Official Analytical Chemists (1997), and the carbohydrate content was calculated by difference $[100-$ (protein + lipids + moisture + ash + total dietary fibers)]. The energy content was calculated according to Menezes et al. (2016) summing the products of protein, carbohydrate, lipid, and dietary fiber content by $4,4,9$, and $2 \mathrm{kcal} \mathrm{g}^{-1}$, respectively $[4 \mathrm{x}$ protein $+4 \mathrm{x}$ carbohydrate $+9 \mathrm{x}$ lipid $+2 \mathrm{x}$ dietary fiber] and by combustion calorimetry analyzing the Superior Calorific Power (PCS) experimentally determined in an adiabatic calorimeter (PARR 6200 Calorimeter), according to the method described by Santos (2010). The PCS value was experimentally determined and multiplied by the respective coefficient of digestibility for fruits (0.85), as described by Merrill \& Watt (1973), to obtain the energy value (kcal $100 \mathrm{~g}^{-1}$ ).

\subsubsection{Morphology, flowability, and powder solubility}

The morphology of the Bacaba powder was analyzed by scanning electron microscopy (SEM), using VEGA3 (TESCAN, Kohoutovice, Czech Republic). Flowability was determined using the Carr index $(C I)$, calculated from Equation 2 (Turchiuli et al., 2005), which relates to the values of specific bulk ( $\left.\rho_{b u l k}\right)$ and tapped $\left(\rho_{\text {tapped }}\right)$ masses. Specific bulk mass was obtained by weighing Bacaba powder equivalent to a volume of $10 \mathrm{~mL}$ in a beaker, and compacted specific mass was measured by lightly tapping 180 times the beaker containing the same sample amount for determining specific bulk mass (Chever et al., 2017).

$$
C I=\frac{\left(\rho_{\text {tapped }}-\rho_{\text {bulk }}\right)}{\rho_{\text {tapped }}} \times 100
$$

The method described by Cano-Chauca et al. (2005) was used to determine the solubility of the powdered mixture in water. Solubility (\%) was calculated based on the difference between the initial solid mass used in the analysis $(1 \mathrm{~g})$ and the resultant solid mass in the aliquot supernatant. 


\subsection{Statistical analysis}

The experimental design of Box \& Behnken (1960) was used for designing the Bacaba spouted bed drying assays. Fifteen experimental runs were performed, for which operational input variables were studied; their respective coded values are shown in Table 1 . The response variables analyzed were: process yield $(\mathrm{Y})$, final powder moisture content (MC), anthocyanin retention (AR), and total phenolic compound retention (TPCR). The process yield was determined according to Equation 3 by relating the collected powder mass ( $m_{\text {powder }}$ in the cyclone with the total mass of the paste $\left(\mathrm{m}_{\mathrm{paste}}\right.$ ) added to the spouted bed for each experiment, on a dry base.

$$
Y=100 \times \frac{m_{\text {powder }}\left(1-M C_{\text {powder }}\right)}{m_{\text {paste }}\left(1-M C_{\text {paste }}\right)}
$$

The second order polynomial model generated for this type of design is shown in Equation 4, where $\hat{Y}$ corresponds to each of the response variables, $x_{i}$ is the coded level of the design variables, $n$ is the number of operational variables, $b_{0}$ is a constant, and $b_{i}, b_{i i}$, and $b_{i j}$ are the regression coefficients of the linear, quadratic, and interaction terms, respectively.

$$
\hat{Y}=b_{0}+\sum_{i=1}^{n} b_{i} x_{i}+\sum_{i=1}^{n} b_{i i} x_{i}^{2}+\sum_{i<j}^{n} b_{i j} x_{i} x_{j}
$$

Verification of the quality of the proposed models was based on the coefficient of determination $\left(\mathrm{R}^{2}\right)$, independence, normality, homogeneity of residue variance (Bartlett's test and Levene's test), and absence of outliers. Statistical analyses were performed using Statistica ${ }^{\circledR} 13.1$ (DELL Inc., CA, USA) at significance level $\alpha=0.05$. To optimize multiple responses simultaneously, the global desirability function was applied (Derringer \& Suich, 1980).

\section{Results and discussion}

\subsection{Characterization of Bacaba-maltodextrin pastes}

The content of various components of the Bacaba pulp was as follows: moisture $87.06 \pm 1.08 \mathrm{~g}^{100 \mathrm{~g}^{-1}}$

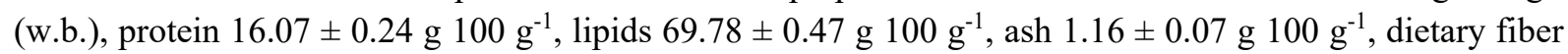

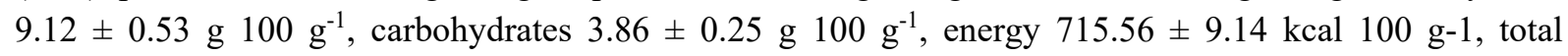
anthocyanins $9.57 \pm 2.34 \mathrm{mg} 100 \mathrm{~g}^{-1}$ (expressed as cyanidin-3-glucoside), and total phenolics $453.26 \pm 0.75 \mathrm{mg}$ GAE $100 \mathrm{~g}^{-1}$. After dilution, different maltodextrin proportions were added to the Bacaba pulp; their characteristics are summarized in Table 2. Contact angles greater than $70^{\circ}$ were observed for all Bacaba-maltodextrin pastes, which indicate that the spouted bed drying of these pulps using HDPE is favorable (Rocha et al., 2009).

\subsection{Evaluation of experimental design}

The responses obtained after spouted bed drying of the pastes are shown in Table 1. The pressure drop curves obtained in the fluid dynamics analysis showed typical spouting profiles as described by Mathur \& Epstein (1974), and the $V_{j m}$ values at $55^{\circ} \mathrm{C}, 65^{\circ} \mathrm{C}$, and $75^{\circ} \mathrm{C}$ were $21.62,19.75$, and $19.01 \mathrm{~m} \mathrm{~s}^{-1}$, respectively. 
Table 1. Experimental design matrix of Box and Behnken with real and coded variables and experimental results.

\begin{tabular}{cccccccc}
\hline \multirow{2}{*}{ Tests } & \multicolumn{3}{c}{ Independent variables } & \multicolumn{3}{c}{ Response variables } \\
\cline { 2 - 8 } & $\boldsymbol{T}\left(\boldsymbol{X}_{\boldsymbol{1}}\right)$ & $\boldsymbol{M}\left(\boldsymbol{X}_{2}\right)$ & $\boldsymbol{V}\left(\boldsymbol{X}_{3}\right)$ & $\boldsymbol{Y}$ & $\boldsymbol{M C}$ & $\boldsymbol{A R}$ & $\boldsymbol{F} \boldsymbol{R}$ \\
\hline 1 & $55(-1)$ & $15(-1)$ & $1.25 \times \mathrm{V}_{\mathrm{jm}}(0)$ & 33.06 & 10.14 & 76.22 & 83.02 \\
\hline 2 & $75(1)$ & $15(-1)$ & $1.25 \times \mathrm{V}_{\mathrm{jm}}(0)$ & 35.59 & 5.87 & 16.98 & 78.85 \\
\hline 3 & $55(-1)$ & $25(1)$ & $1.25 \times \mathrm{V}_{\mathrm{jm}}(0)$ & 25.67 & 10.07 & 82.51 & 59.74 \\
\hline 4 & $75(1)$ & $25(1)$ & $1.25 \times \mathrm{V}_{\mathrm{jm}}(0)$ & 49.55 & 5.72 & 23.01 & 65.56 \\
\hline 5 & $55(-1)$ & $20(0)$ & $1.2 \times \mathrm{V}_{\mathrm{jm}}(-1)$ & 31.73 & 10.20 & 80.09 & 68.56 \\
\hline 6 & $75(1)$ & $20(0)$ & $1.2 \times \mathrm{V}_{\mathrm{jm}}(-1)$ & 56.41 & 6.21 & 23.13 & 72.93 \\
\hline 7 & $55(-1)$ & $20(0)$ & $1.3 \times \mathrm{V}_{\mathrm{jm}}(1)$ & 33.62 & 9.82 & 74.68 & 95.38 \\
\hline 9 & $75(1)$ & $20(0)$ & $1.3 \times \mathrm{V}_{\mathrm{jm}}(1)$ & 52.63 & 5.68 & 37.52 & 79.76 \\
\hline 10 & $65(0)$ & $15(-1)$ & $1.2 \times \mathrm{V}_{\mathrm{jm}}(-1)$ & 38.84 & 8.91 & 73.94 & 87.04 \\
\hline 11 & $65(0)$ & $25(1)$ & $1.2 \times \mathrm{V}_{\mathrm{jm}}(-1)$ & 48.50 & 8.78 & 80.09 & 66.37 \\
\hline 12 & $65(0)$ & $15(-1)$ & $1.3 \times \mathrm{V}_{\mathrm{jm}}(1)$ & 45.44 & 8.60 & 82.43 & 88.34 \\
\hline 13 & $65(0)$ & $25(1)$ & $1.3 \times \mathrm{V}_{\mathrm{jm}}(1)$ & 52.16 & 8.51 & 82.35 & 73.07 \\
\hline 14 & $65(0)$ & $20(0)$ & $1.25 \times \mathrm{V}_{\mathrm{jm}}(0)$ & 51.10 & 8.70 & 92.52 & 82.51 \\
\hline
\end{tabular}

$T=$ Drying air temperature $\left({ }^{\circ} \mathrm{C}\right) . M=$ Maltodextrin concentration $(\% \mathrm{w} / \mathrm{w}) . V=$ Drying air velocity $\left(\mathrm{m} \mathrm{s}^{-1}\right) . V_{j m}=$ Minimal spouting velocity. $Y=$ Process yield (\%). $M C=$ Moisture content ( $100 \mathrm{~g}^{-1}$ w.b.). $A R=$ Anthocyanin retention (\%). $F R=$ Phenolic retention (\%).

The regression coefficients that allow the construction of the polynomial model for each analyzed response are summarized in Table 3. The coefficients of determination $\left(R^{2}\right)$ were adequate $(>0.895)$ for all the response variables, indicating the percentage of experimental variance explained by the proposed regression equations.

Table 2. Characterization of diluted Bacaba pulp and of the Bacaba-maltodextrin pastes.

\begin{tabular}{|c|c|c|c|c|}
\hline \multirow{2}{*}{ Properties } & \multicolumn{2}{|c|}{ Diluted Bacaba } & \multicolumn{2}{|c|}{ Bacaba-maltodextrin pastes } \\
\hline & $3: 1(w / w)$ & $85 \%-15 \%(w / w)$ & $80 \%-20 \%(w / w)$ & $75 \%-25 \%(w / w)$ \\
\hline Density $\left(\mathrm{kg} \mathrm{m}^{-3}\right)$ & $1120.08 \pm 0.01$ & $1180.16 \pm 0.01$ & $1190.48 \pm 0.01$ & $1210.35 \pm 0.01$ \\
\hline Solid concentration $\left(\mathrm{g} 100 \mathrm{~g}^{-1}\right)$ & $11.08 \pm 0.52$ & $20.17 \pm 0.36$ & $25.60 \pm 0.59$ & $29.25 \pm 0.45$ \\
\hline Contact angle $\left({ }^{\circ}\right)$ & $68.5 \pm 0.80$ & $74.9 \pm 0.70$ & $80.2 \pm 1.00$ & $82.5 \pm 1.50$ \\
\hline $\begin{array}{c}\text { Total anthocyanins } \\
\left.\text { (mg } 100 \mathrm{~g}^{-1} \text { cyn-3-glu d.b. }\right)^{\dagger}\end{array}$ & $7.31 \pm 0.31$ & $6.85 \pm 0.03$ & $6.55 \pm 0.02$ & $6.24 \pm 0.04$ \\
\hline Total phenolic (mg GAE $100 \mathrm{~g}^{-1}$ d.b.) & $448.26 \pm 0.84$ & $444.39 \pm 0,57$ & $437.05 \pm 0.42$ & $433.22 \pm 0.49$ \\
\hline
\end{tabular}

$\dagger$ cyanidin-3-glucoside. \$gallic acid equivalent. d.b.: dry basis.

\subsubsection{Effect of operational variables on process efficiency and powder final moisture content}

Changes in operational input variables $X_{1}$ and $X_{2}$ positively affected the yield of the Bacaba spouted bed drying process (Table 3 ); higher temperature and maltodextrin concentrations promoted a higher process yield (Figure 2A). With respect to the positive influence of temperature, this finding is consistent with the results for the spouted bed drying of açaí (Euterpe oleracea Mart.) pulp (Costa et al., 2015) and of papaya (Carica papaya) seeds for oil production (Chielle et al., 2016). 
Table 3. Analysis of variance for the effects of operational variables in each response variable and coefficients for the prediction models.

\begin{tabular}{|c|c|c|c|c|c|c|c|c|c|c|c|c|c|}
\hline \multirow{2}{*}{ Source } & \multirow{2}{*}{$\mathbf{d f}^{\dagger}-$} & \multicolumn{3}{|c|}{ Process yield } & \multicolumn{3}{|c|}{ Moisture content } & \multicolumn{3}{|c|}{ Anthocyanin retention } & \multicolumn{3}{|c|}{ Phenolic retention } \\
\hline & & Coef. ${ }^{\star}$ & $\mathbf{S S}^{\S}$ & $\mathbf{p}$ & Coef. & $\mathbf{S S}^{\S}$ & $\mathbf{p}$ & Coef. ${ }^{\ddagger}$ & $\mathbf{S S}^{\S}$ & p & Coef. & $\mathbf{S S}^{\S}$ & p \\
\hline$X_{1}$ & 1 & 8.7632 & 4.3558 & $0.0029 *$ & -2.0937 & 35.0703 & $0.0001 *$ & -26.6091 & 5664.3591 & $0.0003^{*}$ & -1.1997 & 11.5139 & 0.4940 \\
\hline$X_{2}$ & 1 & -8.1100 & 65.8577 & $0.0264 *$ & -0.7304 & 0.0242 & 0.1066 & -33.7161 & 142.2513 & $0.0368^{*}$ & -3.1052 & 657.4818 & $0.0245^{*}$ \\
\hline$X_{3}$ & 1 & 2.8692 & 8.7399 & 0.1591 & -0.0550 & 0.2775 & $0.0108^{*}$ & 2.2981 & 48.7259 & $0.0322 *$ & -9.0656 & 216.7750 & 0.0693 \\
\hline$X_{I}^{2}$ & 1 & -5.4751 & 242.8475 & $0.0074^{*}$ & -0.0079 & 1.9699 & $0.0015^{*}$ & -7.8674 & 4197.3151 & $0.0004 *$ & -3.5552 & 35.6012 & 0.2820 \\
\hline$X_{2}^{2}$ & 1 & 1.0452 & 110.6834 & $0.0160^{*}$ & -0.1862 & 0.0002 & 0.8091 & 2.4679 & 228.5395 & $0.0071^{*}$ & 5.2055 & 46.6683 & 0.2368 \\
\hline$X_{3}^{2}$ & 1 & 546 & 17.1410 & 0.0913 & 0.0196 & 0.0014 & 0.5664 & -3.6920 & 50.3301 & $0.0312^{*}$ & 3.8081 & 53.5442 & 0.2155 \\
\hline$X_{1} X_{2}$ & 1 & 5.3382 & 113.9832 & $0.0155^{*}$ & -0.0200 & 0.0016 & 0.5447 & -0.0651 & 0.0170 & 0.9284 & 2.4965 & 24.9304 & 0.3466 \\
\hline$X_{1} X_{3}$ & 1 & -1.4168 & 8.0293 & 0.1698 & -0.0375 & 0.0056 & 0.3079 & 4.9486 & 97.9535 & $0.0164^{*}$ & -4.9971 & 99.8825 & 0.1345 \\
\hline$X_{2} X_{3}$ & 1 & -0.7333 & 2.1507 & & 0.0100 & 0.0004 & 0.7522 & -1.5582 & 9.7119 & 0.1358 & 1.3486 & 7.2754 & 0.5774 \\
\hline Lack of Fit & 3 & & 67.7477 & 0.0751 & & 0.0436 & 0.1787 & & 81.0281 & 0.0580 & & 103.2428 & 0.3437 \\
\hline Pure Error & 2 & & 3.6197 & & & 0.0061 & & & 3.2924 & & & 33.4606 & \\
\hline Total & 14 & & 1251.2039 & & & 37.4275 & & & 10249.9070 & & & 1299.5245 & \\
\hline$b 0^{\pi}$ & & 49.5529 & & & 8.6883 & & & 91.2617 & & & 78.4530 & & \\
\hline $\mathrm{R}^{2}$ & & & 0.943 & & & 0.999 & & & 0.992 & & & 0.895 & \\
\hline
\end{tabular}

$\dagger$ degrees of freedom. $\ddagger$ regression coefficient. §Sum of square. $\uparrow$ Intercepto. ${ }^{*} p<0.05$ (Statistically significant values).

Thus, it is understood that the increase in temperature of the spouted bed promotes high heat transfer rates, which contributes to improved paste drying and increased rate of powder formation. Pastes with higher concentrations of maltodextrin revealed a tendency to increase powder yield. This behavior occurs due to a possible increase in the glass transition temperature of the suspension, caused by the addition of high molecular weight compounds such as maltodextrin (Cano-Chauca et al., 2005). The result is the prevention of agglomerates formation on the dryer wall avoiding low yield, even in suspension with high evidence of sugar, such as Bacaba. Similar behaviors were observed in studies of Fujita et al. (2013) and Santiago et al. (2016) in the production of Camu-Camu and Pomegranate powder.

$X_{1}$ and $X_{3}$ were the only variables that had a significant effect on the moisture content of spouted-bed-dried Bacaba powder (Table 3). Higher velocities supposedly increases the solid-fluid surface contact, which facilitates mass transfer, thereby reducing the moisture content of the material.

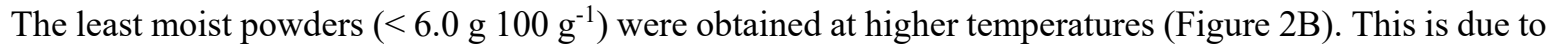
the high heat transfer rates, which provide the necessary and sufficient driving force for establishing positive differences in the partial water vapor pressure between the moisture contained on the surface of the material and the humidity of the surrounding air, which enable high mass transfer rates. This is a desirable property

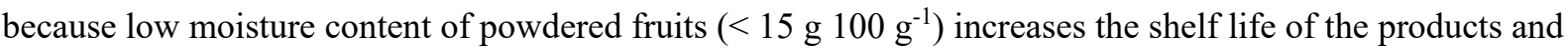
decreases microorganism proliferation (Brasil, 2005; Food and Agriculture Organization, 2007). 


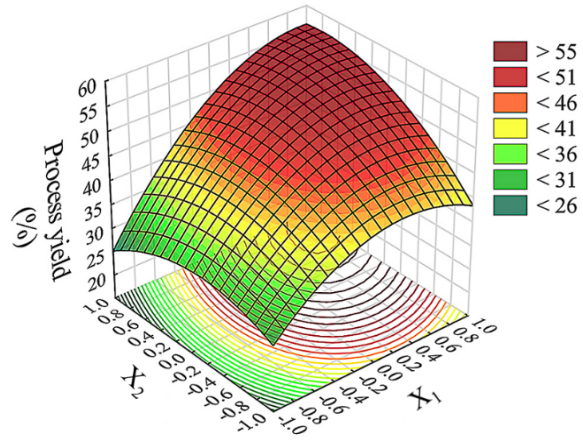

(A)

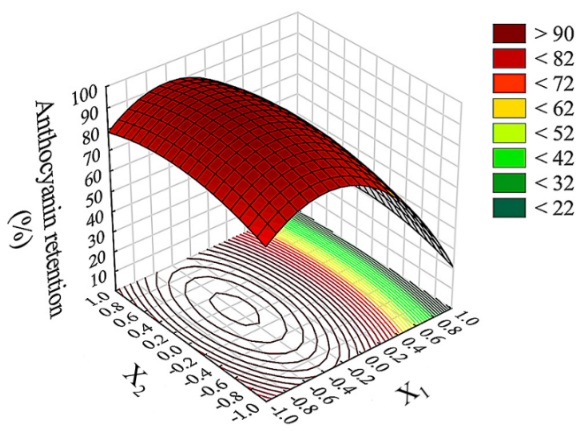

(C)

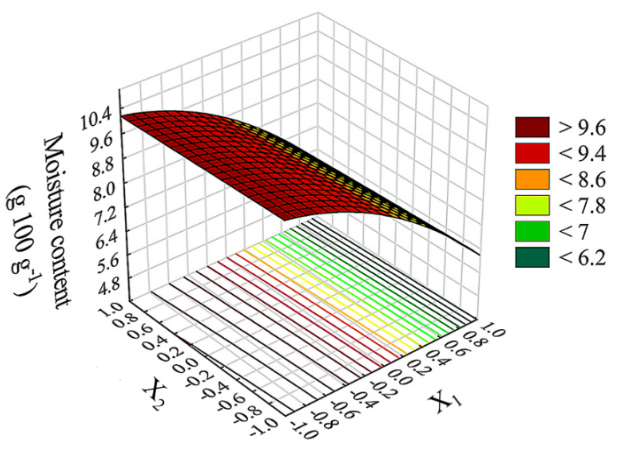

(B)

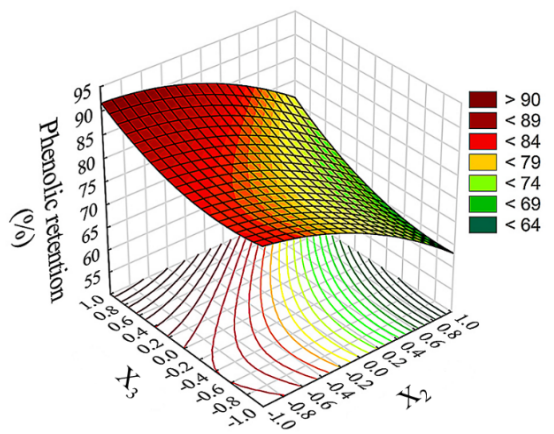

(D)

Figure 2. Response surface of the $(\mathrm{A})$ process yield for $\mathrm{X}_{3}=0$, drying air velocity of $1.25 \times \mathrm{Vjm}\left(\mathrm{m} . \mathrm{s}^{-1}\right)$; (B) moisture content for $\mathrm{X}_{2}=0$, maltodextrin concentration of $20 \%(\mathrm{w} / \mathrm{w}) ;(\mathrm{C})$ retention of anthocyanins for $\mathrm{X}_{3}=0$, drying air

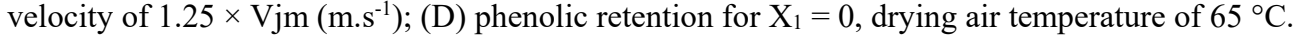

\subsubsection{Effect of operational input variables on anthocyanin and phenolic compound retention}

The powdered Bacaba showed anthocyanin retention of 16.98 at $92.52 \%$ (Table 1), corresponding to a

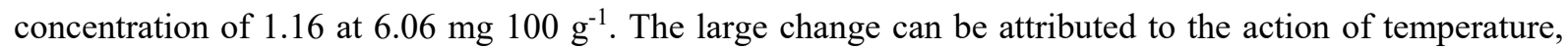
whose influence was highly significant ( $p=0.0003$, Table 3 ). This effect is consistent with our predictions because these pigments are extremely temperature-labile (Castañeda-Ovando et al., 2009). The response surface revealed lower anthocyanin retention values when approaching the maximum temperature (Figure 2C). These constituents are therefore likely to degrade considerably at temperatures close to $75^{\circ} \mathrm{C}$, as previously described (Kirca et al., 2007). The region of greatest retention of anthocyanins in the process is indicated in Table 1 as corresponding to the central point $\left(X_{1}, X_{2}\right.$ and $\left.X_{3}=0\right)$, and is clearly shown in Figure $2 \mathrm{C}$. The value of $92.52 \%$ is higher than the data described in the literature for pulps dried in spray dryers, where, on average, retention of these constituents is approximately $60 \%$ to $75 \%$ (Santiago et al., 2016).

For phenolic compounds, retention varied from $59.74 \%$ to $95.38 \%$, corresponding to concentrations of 258.81-416.86 mg EAG $100 \mathrm{~g}^{-1}$. Wilkowska et al. (2016) obtained 73\% retention of phenolic compounds for blueberry (Vaccinium myrtillus) using a spray dryer.

Analysis of variance (Table 3) indicated that the concentration of maltodextrins $\left(X_{2}\right)$ had a significant negative effect on the retention of phenolic compounds (see also Figure 2D). Moreover, Fujita et al. (2013) observed this effect during spouted bed drying of camu-camu (Myrciaria dubia McVaugh) pulp, where powders resulting from pastes formulated with lower maltodextrin content had higher amounts of phenolic constituents, after accounting for the dilution effect. Thus, the addition of the carrier agent at lower concentrations is related to the increase in the amount of Bacaba inserted into the spouted bed, because the lower the maltodextrin proportion, the greater the bulk amount of Bacaba present in the formulation (Table 2). 


\subsection{Simultaneous optimization}

Table 4 presents the parameters used in the global desirability function to obtain a higher yield, and anthocyanin and phenolic retentions, in addition to lower moisture content.

Table 4. Parameters assumed in the global desirability function.

\begin{tabular}{|c|c|c|c|c|c|}
\hline \multirow{2}{*}{ Response variables } & \multicolumn{5}{|c|}{ Parameters assumed in optimization } \\
\hline & Low & Medium & High & $\mathbf{s}$ & $\mathbf{t}$ \\
\hline Process yield (\%) & $25.67(0)$ & $41.04(0)$ & $56.41(1)$ & 2 & 2 \\
\hline Moisture content (g $100 \mathrm{~g}^{-1}$ w.b.) & $10.20(0)$ & $7.94(1)$ & $5.68(1)$ & 2 & 2 \\
\hline Anthocyanin retention $(\%)$ & $16.98(0)$ & $80.00(1)$ & $92.52(1)$ & 2 & 2 \\
\hline Phenolic retention $(\%)$ & $59.74(0)$ & $80.00(1)$ & $95.38(1)$ & 2 & 2 \\
\hline
\end{tabular}

(0) Unacceptable values. (1) Acceptable values for the desirability function. $s$ and $t$ : Exponents of the desirability function.

Figure 3 shows the operating conditions $\left(X_{1}=0.27 ; X_{2}=0.33 ; X_{3}=1\right)$ that allowed for maximization of Bacaba drying in the spouted bed, indicating an overall desirability coefficient of 0.9969 , which is considered excellent (Lazić, 2004). The design variables obtained in the simultaneous optimization were decoded according to a previously described method (Myers et al., 2009). The following conditions were found to be optimal: drying temperature of $68{ }^{\circ} \mathrm{C}$, maltodextrin concentration of $21.7 \% \mathrm{w} / \mathrm{w}$, and air velocity of $1.3 \times V_{j m} \mathrm{~m} \mathrm{~s}^{-1}$.

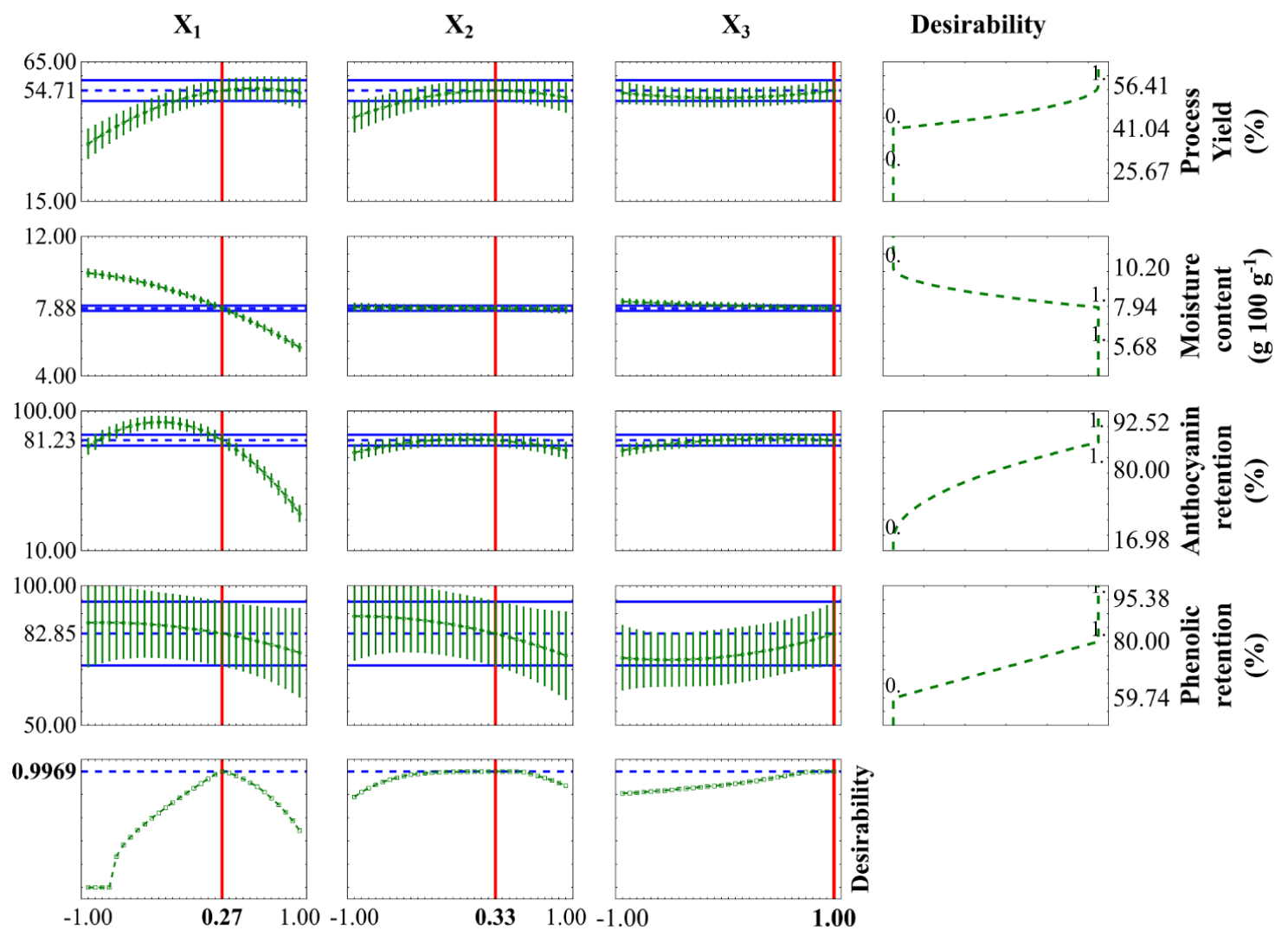

Figure 3. Graph of the desirability function for the simultaneous optimization of the variables.

Under these experimental conditions, the yield of the process was $55.04 \pm 1.5 \%$, with moisture content of

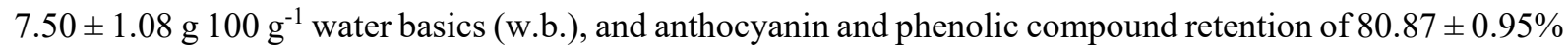
and $83.05 \pm 1.2 \%$, respectively. We found that these experimental values are very close to the values predicted by the desirability function (Figure 3), which validates the efficiency of this simultaneous optimization technique. 


\subsection{Characterization of Bacaba powder}

The composition of Bacaba powder obtained under operating conditions determined by the desirability

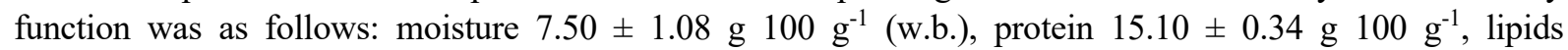

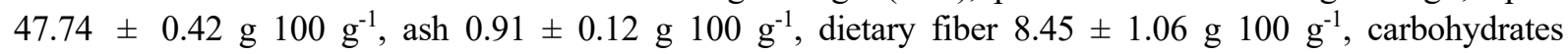

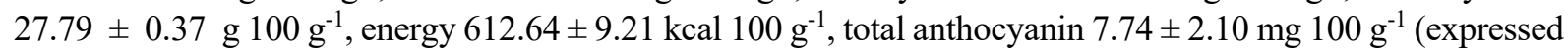
as cyanidin-3-glucoside), and total phenolics $376.43 \pm 1.20 \mathrm{mg}$ GAE $100 \mathrm{~g}^{-1}$. The lipid content decreased considerably, to half that of Bacaba pulp in natura, probably due to the adhesion of lipid constituents to HDPE particles and contact with the equipment walls. The carbohydrate content of the powder was significantly higher than that of the pulp in natura, probably due to the addition of maltodextrin, which also explains the high energetic value obtained. We noted that the produced powder is rich in dietary fibers and proteins, although small reductions in these properties occurred as compared with the pulp in natura.

The flowability index $(C I)$ was $14 \%$, being characterized as excellent $(<15 \%)$ (Turchiuli et al., 2005). This parameter is important to ensure non-cohesive powders and may also have some effect on production quality and reliability (Zafar et al., 2017). The solubility of $92 \%$ indicated a high capacity of the powder to remain in a homogeneous mixture with water. This value is affected by the presence of maltodextrin, which has a highly soluble character (Cano-Chauca et al., 2005). Therefore, the high solubility of Bacaba powder could facilitate its incorporation and use in instant products in which rapid dissolution is required.

SEM analysis showed the presence of spherical microparticles (Figure 4A), supposedly maltodextrin, adhered and aggregated into larger and irregular particles (Figure 4B), which were probably Bacaba powder fibers, exemplifying the supposed encapsulating character of maltodextrin towards anthocyanins. In addition, Bacaba powder showed irregular structure (Figure 4C) with the presence of some fusions (flattenings) was noted (Figure 4D) that may be associated with the mechanical deformations that the material is subjected to during spouted bed.
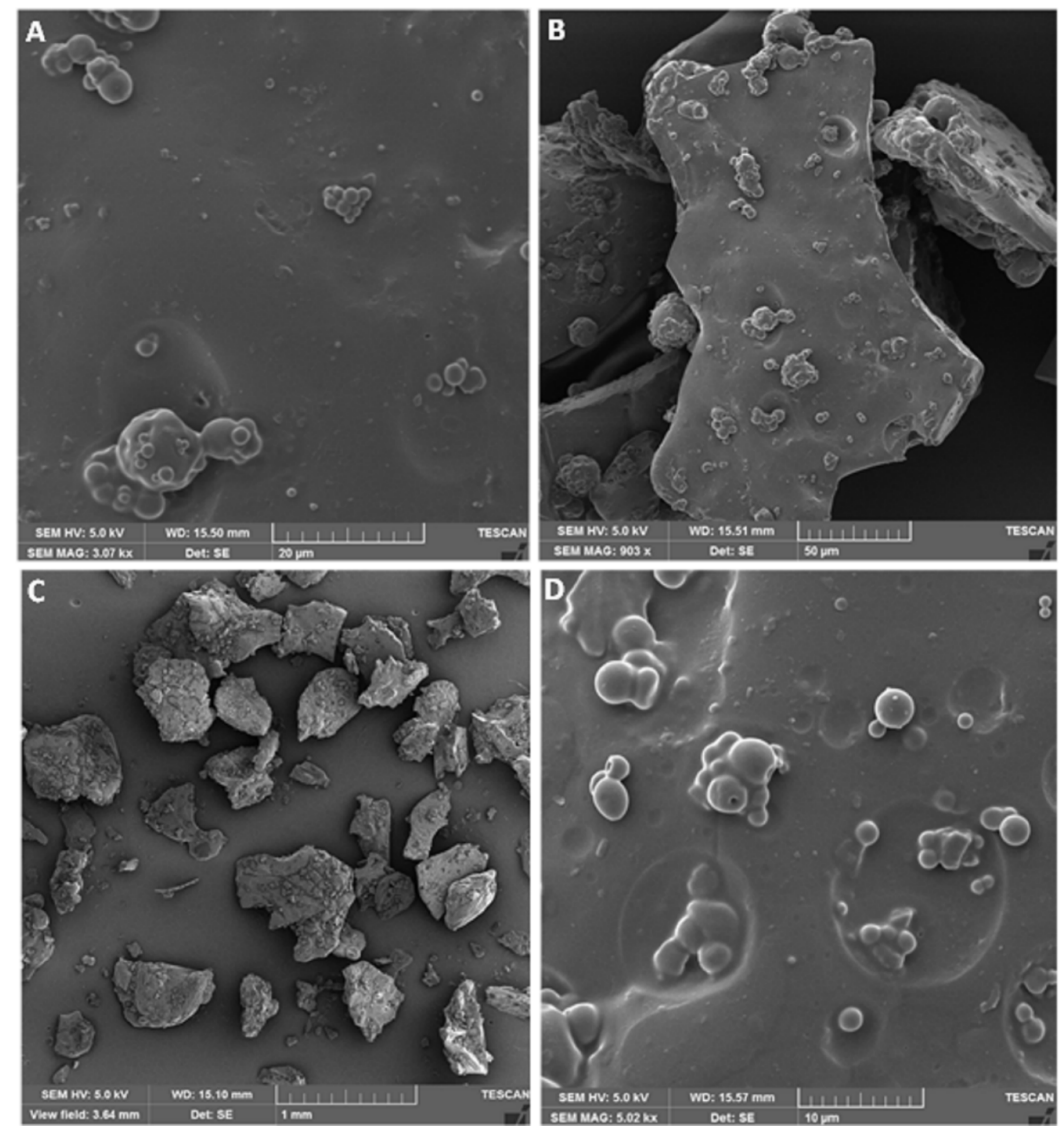

Figure 4. Scanning electron microscopy (SEM) images of Bacaba powder produced at the optimal spouted bed drying condition; magnifications $3000 \times$ (A), $900 \times$ (B), $3.64 \mathrm{~mm}$ view field (C) and $5000 \times$ (D). 


\subsubsection{Energetic Value (EV)}

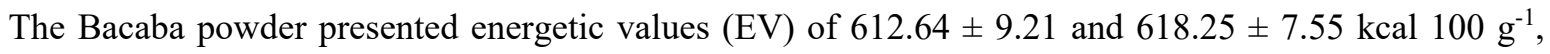
obtained by the 4-4-9-2 method and by combustion calorimetry, respectively. No significant differences were observed when the results were compared with Tukey's test $(p<0.05)$. We compared our results with

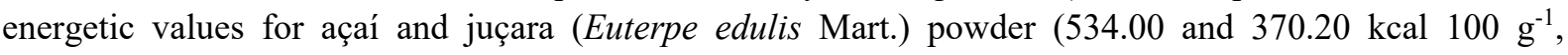
respectively), recommended by Murdock \& Schauss (2009) as a food supplement, and determined that Bacaba powder has high incorporation potential as an energy additive for athletes. Potgieter (2013) determined that the caloric requirements for elite athletes can be up to $12,000 \mathrm{kcal} \mathrm{day}^{-1}$. To meet this need, athletes commonly use dietary supplements in order to preserve the nutritional balance in energy budgets.

The high EV of Bacaba powder is largely owing to the content of lipids and carbohydrates, approximately $64 \%$ and $17 \%$, respectively, of the total caloric value. The high lipid content of Bacaba powder is an intrinsic feature of the product and originates from the pulp. Seixas et al. (2016) analyzed the lipid profile of Bacaba pulp and determined that it is rich in fatty acids, mainly oleic acid, which is essential for its cardiovascular protective function, and increases the number of hepatic receptors to low density lipoprotein (LDL), thus reducing the production and blood circulation of LDLs.

\subsubsection{Total Anthocyanin (TA) and Total Phenolic (TP) content}

The TA concentration in Bacaba powder $\left(7.74 \pm 2.10 \mathrm{mg} 100 \mathrm{~g}^{-1}\right)$ is relevant for comparison with other

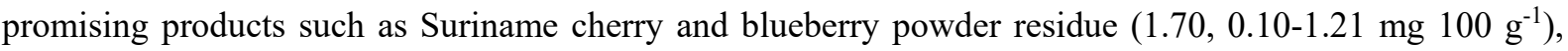
which are recommended by Borges et al. (2016) and Santos et al. (2019) as natural sources of food coloring and raw materials for anthocyanins. The TP concentration in Bacaba powder was $376.43 \pm 1.20 \mathrm{mg}$ GAE $100 \mathrm{~g}^{-1}$, presenting a $17 \%$ degradation from that of the in natura pulp. TP values for Bacaba powder that we have produced here are higher than those reported for other products that are widely accepted as antioxidant sources (Table 5).

Table 5. Total phenolics present in bacaba powder compared to other products described in the literature.

\begin{tabular}{|c|c|c|c|c|}
\hline Products in powder & $\begin{array}{l}\text { Scientific name of the plant } \\
\text { and cultivar (cv.) }\end{array}$ & Process & $\begin{array}{c}\text { Total phenolic } \\
\left(\mathrm{mg} \mathrm{GAE} 100 \mathrm{~g}^{-1}\right)^{\dagger}\end{array}$ & References \\
\hline Bacaba & Oenocarpus bacaba Mart. & Spouted bed & $376.43 \pm 1.2$ & \\
\hline Cherry (juice and paste) & Prunus cerasus cv. Marasca & Spray drying & $\begin{array}{c}134.59 \pm 2.7 \\
98.07 \pm 0.1\end{array}$ & Zorić et al. (2017) \\
\hline Guava (fruit) & Psidium guajava $\mathrm{L}$. & Freeze drying & $88.07 \pm 3.9$ & $\begin{array}{l}\text { Nunes et al. } \\
\quad(2016)\end{array}$ \\
\hline Banana (fruit) & $\begin{array}{l}\text { Musa nana } \\
\text { Musa cavendishii }\end{array}$ & $\begin{array}{l}\text { Freeze drying } \\
\text { Convective drying } \\
\text { Freeze drying } \\
\text { Convective drying }\end{array}$ & $\begin{array}{c}129.00 \pm 10.0 \\
157.00 \pm 7.0 \\
1.66 \pm 12.0 \\
116.00 \pm 2.0\end{array}$ & $\begin{array}{l}\text { Guiné et al. } \\
\text { (2015) } \\
\text { Guiné et al. } \\
\text { (2015) }\end{array}$ \\
\hline Melon (pulp) & Cucunis melo & Freeze drying & $315.45 \pm 71.7$ & $\begin{array}{l}\text { Morais et al. } \\
\quad(2015)\end{array}$ \\
\hline Papaya (pulp) & Carica papaya & Freeze drying & $325.97 \pm 64.5$ & $\begin{array}{l}\text { Morais et al. } \\
\text { (2015) }\end{array}$ \\
\hline Watermelon (pulp) & Citrullus lanatus & Freeze drying & $241.99 \pm 22.2$ & $\begin{array}{l}\text { Morais et al. } \\
\quad(2015)\end{array}$ \\
\hline Pineaaple (residue) & Ananas comosus & Convective drying & $275.00 \pm 38.0$ & $\begin{array}{l}\text { Oliveira et al. } \\
\text { (2009) }\end{array}$ \\
\hline Acerola (residue) & Malpighia emarginata & Convective drying & $681.00 \pm 53.5$ & $\begin{array}{l}\text { Oliveira et al. } \\
\text { (2009) }\end{array}$ \\
\hline Passion fruit (residue) & Passiflora alata & Convective drying & $103.00 \pm 10.4$ & $\begin{array}{l}\text { Oliveira et al. } \\
(2009)\end{array}$ \\
\hline
\end{tabular}


The value of TP is considered to be excellent because $100 \mathrm{~g}$ of Bacaba powder represents approximately $84 \%$ and $81 \%$ of average daily intake of TP $(450$ and $460 \mathrm{mg}$ ) from vegetables and fruits in USA and Brazil, respectively (Chun et al., 2005; Corrêa et al., 2015). When compared with the dietetic digestion (DRI), which is $828 \mathrm{mg}$ recommended by Williamson \& Holst (2008), the TP content of $100 \mathrm{~g}$ of Bacaba powder constitutes $45 \%$ of the TP ingestion reference.

Thus, this Bacaba fruit co-product can be considered a good natural antioxidant source because of the presence of the components that have the ability to destroy radicals and to fight diseases. Furthermore, in the food industry, substitution of synthetic antioxidants, such as butylhydroxyanisole (BHA) and butylhydroxytoluene (BHT), by natural antioxidants acting as retarders of lipid oxidation is recommended by the Food and Agriculture Organization (FAO) and World Health Organization (WHO), since synthetic antioxidants may present toxic effects causing even carcinogenesis (Botterweck et al., 2000). Therefore, Bacaba powder, as a food or an additive, has the potential to be an excellent alternative natural antioxidant source and can be used to improve food quality. The use of water in the extraction process (as in this study), in contrast to other solvents, is another advantage of Bacaba powder, mainly because of food safety and low production cost, since the consumption of in natura or minimally processed food, such as Bacaba powder, should form the basis of nutrition, bringing high health benefits.

\section{Conclusions}

The present study focused on Bacaba powder obtained by spouted bed drying. It is a rich source of phenolic compounds and is a high-energy food, which can be used for the formulation of functional products. The drying process in the spouted bed was most affected by temperature and maltodextrin concentration. The greatest rate of phenolic compound retention was obtained with low maltodextrin concentration. The Bacaba powder obtained at ideal drying conditions showed increased levels of lipids, fibers, carbohydrates, and high energy value. Thus, excellent fluidity, solubility, and morphological features were obtained by the spouted bed process.

We report higher phenolic content for Bacaba powder than for other products and by-products already described in the literature and used in industry as sources of these constituent. Its possible intake directly or indirectly is significantly equivalent to the average percentage of total phenolics consumed in the USA and Brazil. The high energy content of Bacaba powder enables its consumption as a dietary supplement for athletes and for people who require a high-calorie daily diet. These characteristics suggest many potential applications of Bacaba powder, such as in the development of food supplements, high-calorie beverages, dairy and instant products, and baking products.

\section{Acknowledgements}

We thank PROPESP/UFPA and FADESP for the language editing services provided and the Coordination for the Improvement of Higher Level Personnel (CAPES) and National Council for Scientific and Technological Development (CNPq; process number 400624/2014-1) for financial support.

\section{References}

Abadio Finco, F. D. B., Böser, S., \& Graeve, L. (2013). Antiproliferative activity of bacaba (Oenocarpus bacaba) and jenipapo (Genipina americana L.) phenolic extracts: A comparison of assays. Nutrition \& Food Science, 43(2), 98-106. http://dx.doi.org/10.1108/00346651311313247

Abadio Finco, F. D. B., Kammerer, D. R., Carle, R., Tseng, W. H., Boser, S., \& Graeve, L. (2012). Antioxidant activity and characterization of phenolic compounds from bacaba (Oenocarpus bacaba Mart.) fruit by HPLC-DAD-MSn. Journal of Agricultural and Food Chemistry, 60(31), 7665-7673. PMid:22788720. http://dx.doi.org/10.1021/jf3007689

Abadio Finco, F. D. B., Kloss, L., \& Graeve, L. (2016). Bacaba (Oenocarpus bacaba) phenolic extract induces apoptosis in the MCF-7 breast cancer cell line via the mitochondria-dependent pathway. Official Journal of the Society of Nutrition and Food Science, 5, 5-15. http://dx.doi.org/10.1016/j.nfs.2016.11.001 
Angelo, P. M., \& Jorge, N. (2007). Phenolic compounds in foods: A brief review. Revista do Instituto Adolfo Lutz, 66, 1-9. Association of Official Analytical Chemists - AOAC. (1997). Official methods of analysis of the Association of Official Analytical Chemists (16th ed.). Gaithersburg: AOAC.

Bhandari, B. R., Datta, N., \& Howes, T. (1997). Problems associated with spray drying of sugar-rich foods. Drying Technology, 15(2), 671-684. http://dx.doi.org/10.1080/07373939708917253

Borges, K. C., Azevedo, J. C., Medeiros, M. D. F., \& Correia, R. T. P. (2016). Physicochemical characterization and bioactive value of tropical berry pomaces after spouted bed drying. Journal of Food Quality, 39(3), 192-200. http://dx.doi.org/10.1111/jfq.12178

Botterweck, A. A. M., Verhagen, H., Goldbohm, R. A., Kleinjans, J., \& Van Den Brandt, P. A. (2000). Intake of butylated hydroxyanisole and butylated hydroxytoluene and stomach cancer risk: Results from analyses in the Netherlands cohort study. Food and Chemical Toxicology, 38(7), 599-605. PMid:10942321. http://dx.doi.org/10.1016/S0278-6915(00)00042-9

Box, G. E. P., \& Behnken, D. W. (1960). Some three level designs for the study of quantitative variables. Technometrics, 2(4), 455-475. http://dx.doi.org/10.1080/00401706.1960.10489912

Brasil. Agência Nacional de Vigilância Sanitária. (2005, agosto 22). Resolução RDC nº 263 de 22 de setembro de 2005. Regulamento Técnico para produtos de cereais, amidos, farinhas e farelos. Diário Oficial da União, Brasília.

Cano-Chauca, M., Stringheta, P. C., Ramos, A. M., \& Cal-Vidal, J. (2005). Effect of the carriers on the microstructure of mango powder obtained by spray drying and its functional characterization. Innovative Food Science \& Emerging Technologies, 6(4), 420-428. http://dx.doi.org/10.1016/j.ifset.2005.05.003

Castañeda-Ovando, A., Pacheco-Hernández, M. L., Páez-Hernández, M. E., Rodríguez, J. A., \& Galán-Vidal, C. A. (2009). Chemical studies of anthocyanins: A review. Food Chemistry, 113(4), 859-871.

http://dx.doi.org/10.1016/j.foodchem.2008.09.001

Chever, S., Méjean, S., Dolivet, A., Mei, F., Den Boer, C. M., Le Barzic, G., Jeantet, R., \& Schuck, P. (2017). Agglomeration during spray drying: Physical and rehydration properties of whole milk/sugar mixture powders. Lebensmittel-Wissenschaft + Technologie, 83, 33-41. http://dx.doi.org/10.1016/j.Iwt.2017.05.002

Chielle, D. P., Bertuol, D. A., Meili, L., Tanabe, E. H., \& Dotto, G. L. (2016). Spouted bed drying of papaya seeds for oil production. Lebensmittel-Wissenschaft + Technologie, 65, 852-860. http://dx.doi.org/10.1016/j.Iwt.2015.09.022

Chun, O. K., Kim, D. O., Smith, N., Schroeder, D., Han, J. T., \& Lee, C. Y. (2005). Daily consumption of phenolics and total antioxidant capacity from fruit and vegetables in the American diet. Journal of the Science of Food and Agriculture, 85(10), 1715-1724. http://dx.doi.org/10.1002/jsfa.2176

Corrêa, V. G., Tureck, C., Locateli, G., Peralta, R. M., \& Koehnlein, E. A. (2015). Estimate of consumption of phenolic compounds by Brazilian population. Revista de Nutrição, 28(2), 185-196. http://dx.doi.org/10.1590/1415-52732015000200007

Costa, R. G., Andreola, K., Mattietto, R. A., Faria, L. J. G., \& Taranto, O. P. (2015). Effect of operating conditions on the yield and quality of açai (Euterpe oleracea Mart.) powder produced in spouted bed. Lebensmittel-Wissenschaft + Technologie, 64(2) 1196-1203. http://dx.doi.org/10.1016/j.Iwt.2015.07.027

Derringer, G., \& Suich, R. (1980). Simultaneous optimization of several response variables. Journal of Quality Technology, 12(4), 214-219. http://dx.doi.org/10.1080/00224065.1980.11980968

Dias, T. R., Alves, M. G., Casal, S., Oliveira, P. F., \& Silva, B. M. (2017). Promising potential of dietary (poly) phenolic compounds in the prevention and treatment of diabetes mellitus. Current Medicinal Chemistry, 24(4), 334-354. PMid:27593957. http://dx.doi.org/10.2174/0929867323666160905150419

Food and Agriculture Organization - FAO. (2007). Instructional manual of the fruit processing toolkit: Dried fruit. Rome: FAO. Retrieved in 2018, November 21, from http:// www.fao.org/3/a-au111e.pdf

Fujita, A., Borges, K., Correia, R., Franco, B. D. G. M., \& Genovese, M. I. (2013). Impact of spouted bed drying on bioactive compounds, antimicrobial and antioxidant activities of commercial frozen pulp of camu-camu (Myrciaria dubia Mc. Vaugh). Food Research International, 54(1), 495-500. http://dx.doi.org/10.1016/j.foodres.2013.07.025

Geldart, D. (1973). Types of gas fluidization. Powder Technology, 7(5), 285-292. http://dx.doi.org/10.1016/00325910(73)80037-3

Georgé, S., Brat, P., Alter, P., \& Amiot, M. J. (2005). Rapid determination of poly-phenols and vitamin c in plant-derived products. Journal of Agricultural and Food Chemistry, 53(5), 1370-1373. PMid:15740008. http://dx.doi.org/10.1021/jf048396b

Giusti, M. M., \& Wrolstad, R. E. (2001). Anthocyanins: Characterization and measurement with UV-visiblespectroscopy. In R. E. Wrolstad (Ed.), Current protocols in food analytical chemistry (pp. F1.2.1-F1.2.13). New York: Wiley.

Guiné, R. P., Barroca, M. J., Gonçalves, F. J., Alves, M., Oliveira, S., \& Mendes, M. (2015). Artificial neural network modelling of the antioxidant activity and phenolic compounds of bananas submitted to different drying treatments. Food Chemistry, 168, 454459. PMid:25172734. http://dx.doi.org/10.1016/j.foodchem.2014.07.094

Kırca, A., Özkan, M., \& Cemeroğlu, B. (2007). Effects of temperature, solid content and pH on the stability of black carrot anthocyanins. Food Chemistry, 101(1), 212-218. http://dx.doi.org/10.1016/j.foodchem.2006.01.019

Lazić, Z. R. (2004). Design of experiments in chemical engineering: A practical guide. Weinhem: John Wiley \& Sons. http://dx.doi.org/10.1002/3527604162.

Leba, L. J., Brunschwig, C., Saout, M., Martial, K., Bereau, D., \& Robinson, J. C. (2016). Oenocarpus bacaba and Oenocarpus bataua leaflets and roots: A new source of antioxidant compounds. International Journal of Molecular Sciences, 17(7), 1014 PMid:27355943. http://dx.doi.org/10.3390/ijms17071014 
Mathur, K. B., \& Epstein, N. (1974). Spouted beds. New York: Academic Press.

Menezes, E. W., Grande, F., Giuntini, E. B., Lopes, T. V., Dan, M. C., Prado, S. B., Franco, B. D., Charrondière, U. R., \& Lajolo, F. M. (2016). Impact of dietary fiber energy on the calculation of food total energy value in the Brazilian Food Composition Database. Food Chemistry, 193, 128-133. PMid:26433298. http://dx.doi.org/10.1016/j.foodchem.2015.01.051

Merrill, A. L., \& Watt, B. K. (1973). Energy value of foods: Basis and derivation (Agriculture Handbook, 74). Washington: United States Department of Agriculture.

Morais, D. R., Rotta, E. M., Sargi, S. C., Schmidt, E. M., Bonafe, E. G., Eberlin, M. N., Sawaya, A. C. H. F., \& Visentainer, J. V. (2015). Antioxidant activity, phenolics and UPLC-ESI (-)-MS of extracts from different tropical fruits parts and processed peels. Food Research International, 77, 392-399. http://dx.doi.org/10.1016/j.foodres.2015.08.036

Murdock, K. A., \& Schauss, A. G. (2009). U.S. Patent No. 7,563,465. Washington: U.S. Patent and Trademark Office.

Myers, R. H., Montgomery, D. C., \& Anderson-Cook, C. M. (2009). Response surface methodology: Process and product optimization using designed experiments. New Jersey: Wiley.

Neri-Numa, I. A., Soriano Sancho, R. A., Pereira, A. P. A., \& Pastore, G. M. (2018). Small Brazilian wild fruits: Nutrients, bioactive compounds, health-promotion properties and commercial interest. Food Research International, 103, 345-360. PMid:29389624. http://dx.doi.org/10.1016/j.foodres.2017.10.053

Nunes, J. C., Lago, M. G., Castelo-Branco, V. N., Oliveira, F. R., Torres, A. G., Perrone, D., \& Monteiro, M. (2016). Effect of drying method on volatile compounds, phenolic profile and antioxidant capacity of guava powders. Food Chemistry, 197(Pt A), 881-890. PMid:26617030. http://dx.doi.org/10.1016/j.foodchem.2015.11.050

Oliveira, A. C., Valentim, I. B., Silva, C. A., Bechara, E. J. H., Barros, M. P., Mano, C. M., \& Goulart, M. O. F. (2009). Total phenolic content and free radical scavenging activities of methanolic extract powders of tropical fruit residues. Food Chemistry, 115(2), 469-475. http://dx.doi.org/10.1016/j.foodchem.2008.12.045

Potgieter, S. (2013). Sport nutrition: A review of the latest guidelines for exercise and sport nutrition from the American College of Sport Nutrition, the International Olympic Committee and the International Society for Sports Nutrition. The South African Journal of Clinical Nutrition, 26(1), 6-16. http://dx.doi.org/10.1080/16070658.2013.11734434

Rocha, S. C. S., Donida, M. W., \& Marques, A. M. M. (2009). Liquid particle surface properties on spouted bed coating and drying performance. Canadian Journal of Chemical Engineering, 87(5), 695-703. http://dx.doi.org/10.1002/cjce.20208

Santiago, M. C. P. D., Nogueira, R. I., Paim, D. R. S. F., Gouvea, A. C. M. S., Godoy, R. L. D., Peixoto, F. M., Pacheco, S., \& Freitas, S. P. (2016). Effects of encapsulating agents on anthocyanin retention in pomegranate powder obtained by the spray drying process. Lebensmittel-Wissenschaft + Technologie, 73, 551-556. http://dx.doi.org/10.1016/j.Iwt.2016.06.059

Santos, R. C. (2010). Food energy values: Example of an experimental determination, using combustion calorimetry. Química Nova, 33, 220-224. http://dx.doi.org/10.1590/S0100-40422010000100038

Santos, S. S., Rodrigues, L. M., Costa, S. G., \& Madrona, G. S. (2019). Antioxidant compounds from blackberry (Rubus fruticosus) pomace: Microencapsulation by spray-dryer and pH stability evaluation. Food Packaging and Shelf Life, 20, 100177. http://dx.doi.org/10.1016/j.fpsl.2017.12.001

Seixas, F. R. F., Sesquim, E. A. R., Raasch, G. S., \& Cíntra, D. E. (2016). Característica físico-química e perfil lipídico da bacaba proveniente da Amazônia ocidental. Brazilian Journal of Food Research, 7, 105-116.

Shahidi, F., \& Ambigaipalan, P. (2015). Phenolics and polyphenolics in foods, beverages and spices: Antioxidant activity and health effects: A review. Journal of Functional Foods, 18, 820-897. http://dx.doi.org/10.1016/j.jf. 2015.06.018

Turchiuli, C., Eloualia, Z., El Mansouri, N., \& Dumoulin, E. (2005). Fluidized bed agglomeration: agglomerates shape and enduse properties. Powder Technology, 157(1-3), 168-175. http://dx.doi.org/10.1016/j.powtec.2005.05.024

Wachiraphansakul, S., \& Devahastin, S. (2007). Drying kinetics and quality of okara dried in a jet spouted bed of sorbent particles. Lebensmittel-Wissenschaft + Technologie, 40(2), 207-219. http://dx.doi.org/10.1016/j.Iwt.2005.11.010

Wilkowska, A., Ambroziak, W., Czyżowska, A., \& Adamiec, J. (2016). Effect of microencapsulation by spray-drying and freezedrying technique on the antioxidant properties of blueberry (Vaccinium myrtillus) juice polyphenolic compounds. Polish Journal of Food and Nutrition Sciences, 66(1), 11-16. http://dx.doi.org/10.1515/pjfns-2015-0015

Williamson, G., \& Holst, B. (2008). Dietary reference intake (DRI) value for dietary polyphenols: are we heading in the right direction? British Journal of Nutrition, 99(Suppl.3), S55-S58. PMid:18598589. http://dx.doi.org/10.1017/S0007114508006867

Zafar, U., Hare, C., Hassanpour, A., \& Ghadiri, M. (2017). Ball indentation on powder beds for assessing powder flowability: Analysis of operation window. Powder Technology, 310, 300-306. http://dx.doi.org/10.1016/j.powtec.2017.01.047

Zorić, Z., Pelaić, Z., Pedisić, S., Garofulić, I. E., Kovačević, D. B., \& Dragović-Uzelac, V. (2017). Effect of storage conditions on phenolic content and antioxidant capacity of spray dried sour cherry powder. Lebensmittel-Wissenschaft + Technologie, 79, 251-259. http://dx.doi.org/10.1016/j.Iwt.2017.01.049

Funding: National Council for Scientific and Technological Development (CNPq) [process number 400624/2014-1]. 